\title{
Microelements and macroelements in the body of the invasive Harris mud crab (Rhithropanopeus harrisii, Maitland, 1874) from the central coast of the South Baltic Sea

\author{
Arkadiusz Nędzarek (D) P Przemysław Czerniejewski • \\ Agnieszka Tórz
}

Received: 1 October 2018 / Accepted: 27 May 2019/Published online: 18 July 2019

(C) The Author(s) 2019

\begin{abstract}
In this study, we determined the levels of essential and non-essential elements in the Harris mud crab (Rhithropanopeus harrisii, Maitland, 1874) from the southern Baltic Sea. Results revealed high levels of $\mathrm{Ca}(246,000 \mathrm{ppm}), \mathrm{Mg}(11,000 \mathrm{ppm}), \mathrm{Na}(8160 \mathrm{ppm})$, $\mathrm{K}(3,780 \mathrm{ppm})$, and $\mathrm{Fe}(1830 \mathrm{ppm})$. The concentrations of essential metals such as $\mathrm{Zn}(62.5 \mathrm{ppm})$ and $\mathrm{Cu}$ $(25 \mathrm{ppm})$ were similar to those recorded in other crab species. The concentrations of non-essential metals such as $\mathrm{Pb}(0.140 \mathrm{ppm}), \mathrm{Cd}(0.0017 \mathrm{ppm})$, and As $(0.288 \mathrm{ppm})$ were well below the International Standards for Maximum Levels for Food. In view of the above, the Harris mud crab from the southern Baltic is safe to be used as a component of well-balanced feeds for terrestrial and aquatic animals.
\end{abstract}

Keywords Crustaceans · Exoskeleton · Feed fish . Essential metals $\cdot$ Heavy metals $\cdot$ Arsenic

\footnotetext{
A. Nędzarek $(\bowtie) \cdot$ A. Tórz

Department of Aquatic Sozology, Faculty of Food Sciences and Fisheries, West Pomeranian University of Technology in Szczecin, Kazimierza Królewicza Street 4, 71-550 Szczecin, Poland e-mail: arkadiusz.nedzarek@zut.edu.pl

P. Czerniejewski

Department of Fisheries Management, Faculty of Food Sciences and Fisheries, West Pomeranian University of Technology in Szczecin, Kazimierza Królewicza Street 4, 71-550 Szczecin, Poland
}

\section{Introduction}

The natural habitat of the Harris mud crab (Rhithropanopeus harrisii) is the brackish estuarine waters of the Atlantic coast, stretching from the northern regions of the Gulf of Mexico to Nova Scotia in Canada (Petersen 2006). In Europe, the first specimens of this species were observed in 1874 in the Zuiderzee River (Netherlands), and in 1936 their presence was confirmed in the Baltic Sea (Buitendijk and Holthuis 1949). Currently, the Harris mud crab has been reported as a non-indigenous species in 21 different countries (Roche and Torchin 2007). In Poland, the Harris mud crab was first recorded in the 1950s in the Vistula Lagoon (Demel 1953), the estuary of the Vistula, and the Gulf of Gdańsk (Kujawa 1957; Turoboyski 1973; Normant et al. 2004).

Research on crab biology in the Gulf of Gdańsk area began with Michalski (1957) and Kujawa (1957), and in the western part of the Baltic Sea by Czerniejewski and Rybczyk (2008) and Czerniejewski (2009). Analyses by Turoboyski (1973), Normant et al. (2004), and Czerniejewski (2009) showed that these small crustaceans, with a carapace width not exceeding $27 \mathrm{~mm}$, are euryhaline animals that mainly feed on detritus and fine zoobenthos. They are preyed upon by fish which are able to regulate their populations in many waters (Turoboyski 1973; Fowler et al. 2013).

The Harris mud crab may be one of the vectors of heavy metal transfer in the trophic pyramid in the coastal zone of the southern Baltic Sea, with significant amounts of these elements being supplied by river 
systems (Szefer 2002). Metals present in the environment are ingested by crabs together with food (from food itself, sediment particles, and water), directly from the water through the respiratory system, and also as a result of adsorption through the carapace (e.g., Nędzarek et al. 2017, 2019). Bottom sediments play a particularly important role here. The bottom sediments in which the crabs live accumulate pollutants and therefore constitute a secondary source in the ecosystem (Fang et al. 2016; $\mathrm{Ke}$ et al. 2017). These sediments provide food and a habitat to benthic organisms, which are then eaten by fish (Demirak et al. 2006; Vicente-Martorell et al. 2009). As a consequence, the quality and safety of seafood may be at risk (Turkmen et al. 2005, Peng et al. 2011).

Crustaceans are a valuable source of high-quality protein, fatty acids, and macroelements and microelements such as $\mathrm{K}, \mathrm{P}, \mathrm{Na}, \mathrm{Ca}, \mathrm{Mg}, \mathrm{Cu}, \mathrm{Fe}$, and $\mathrm{Zn}$ (Moronkola et al. 2011; Erdem et al. 2015; Islam et al. 2016). However, the Harris mud crab is a relatively small crustacean, and too small for human consumption, but may be used as an additive to fish products used in animal feed production (Jimmy and Arazu 2012). The aforementioned elements are those that are essential for the proper development of organisms. However, organisms may also accumulate nonessential toxic elements (e.g., $\mathrm{Hg}, \mathrm{Cd}, \mathrm{Pb}, \mathrm{As}$ ). These elements can permanently enter the food chain and are particularly dangerous for human health. Therefore, they are used as environmental quality indicators and their concentration in food is controlled by various international regulations (e.g., Standard of Maximum Levels of Contaminants in Foods, FAO 2003, Commission Regulation (EC) No. 1881/2006; Council Directive 98/83/EC 1998). Cd, $\mathrm{Pb}$, and As concentrations are also regulated in raw material for animal feed (Directive 2002/32/EC). Therefore, it is important to know and evaluate the levels of elements in the raw material, including heavy metals or other potentially toxic elements such as arsenic.

To date, the population of Harris mud crabs inhabiting the southern Baltic has not been examined in the context of levels of macroelements and microelements, such as $\mathrm{Ca}, \mathrm{Mg}, \mathrm{Na}, \mathrm{K}, \mathrm{Fe}, \mathrm{Zn}$, $\mathrm{Cu}, \mathrm{Al}, \mathrm{Ni}, \mathrm{As}, \mathrm{Pb}$, and $\mathrm{Cd}$. Therefore, the aim of this research was to assess the content of essential and non-essential elements in the Harris mud crab from the central part of the South Baltic coast against the background of environmental conditions (water and bottom sediments).

\section{Material and methods}

Study area

The research area covered the southern coast of the Baltic Sea to a depth of $5 \mathrm{~m}$ near the seaport in Ustka (E $16^{\circ} 50^{\prime} 59.7^{\prime \prime}, \mathrm{N} 54^{\circ} 35^{\prime} 30^{\prime \prime}$ ) (Fig. 1). According to HELCOM CORESET BD 2/2011 (Helcom 2011), this is part of sub-basin no. 38, also known as the Polish coastal waters of the Bornholm Basin. These waters are characterized by moderate annual temperature $\left(13.1{ }^{\circ} \mathrm{C}\right)$, low salinity (7.1 PSU), sandy bottom, and intense mixing of the waters (Krzymiński 2014). This last factor, together with sea currents, causes the dispersion and transfer of small material fractions to deeper areas (so-called accumulation areas). According to Szefer (2002), heavy metals exhibiting affinity for fine particles and organic matter do not accumulate in these shallow sediments, which results in lower concentrations of heavy metals found in bottom sediments in this area compared with deeper Baltic sub-basins (Uścinowicz et al. 2011).

The main source of pollution in the research area is the Ustka seaport located in the estuary of the Stupia River. Antonowicz et al. (2017) showed extremely high heavy metal concentrations in the central area of the port, with lower concentrations in the outport and in the upstream Slupia River. Likewise, the concentration of heavy metals in sediments at nearby beaches decreased with the distance from the port.

Sampling procedure

Twenty-four (24) Harris mud crabs were caught between September 22 and November 6, 2016, using a drag net, off the coast of the central Baltic Sea (near the town of Ustka) (Fig. 1). Each crab was properly cleaned by rinsing with water to remove debris, plankton, and other external adherents. Immediately after sampling, the crabs were stored in a container placed in crushed ice for transport to the laboratory, where they were frozen at $-20{ }^{\circ} \mathrm{C}$ until analysis.

Water samples were taken at 3 sites (4 samples from each site) near the places where the crabs were caught. Pre-cleaned (rinsed at least three times) 1,5-1 polyethylene sampling bottles were immersed about $0.5 \mathrm{~m}$ below the water surface, then stored in a cooler box for transport to the laboratory. Seabed sediment samples $(0-$ $10 \mathrm{~cm}$ ) were also taken using a Peterson grab at the 




Fig. 1 The area of sampling water, bottom sediments, and Harris mud crabs from the southern coast of the Baltic Sea, (ST-station)

same 3 sites (4 samples from each site), kept in ice for transport to the laboratory, then packed in polyethylene bags and frozen at $-20{ }^{\circ} \mathrm{C}$ until analysis. All the samples were kept away from metallic materials to avoid contamination.

After thawing and drying to a constant weight at $90{ }^{\circ} \mathrm{C}$, the whole body (including meat and exoskeleton) of crabs were crushed in an agate mortar. $1 \mathrm{~g} \pm 0.01$ samples were then digested in $10 \mathrm{~mL}$ of concentrated ultrapure $\mathrm{HNO}_{3}$ (Merck, Germany) in a high-pressure microwave digestor, Speedwave Xpert (Bergoff, Eningen Germany), then diluted with Milli-Q water $(18.2 \mathrm{M} \Omega$ ) to $25 \mathrm{~mL}$.

Samples of the habitat sea water were digested with concentrated $\mathrm{HNO}_{3}$ at a ratio of 10:1 sample to acid by volume. Seabed sediments, after thawing and drying to a constant weight at $90^{\circ} \mathrm{C}$, were filtered through a 2-mm sieve, then wetted with deionized water. The sediments were then dried to a constant weight at $90{ }^{\circ} \mathrm{C}$ and digested with concentrated $\mathrm{HNO}_{3}$ at a ratio of $2 \mathrm{~g}$ of sediment to $5 \mathrm{ml}$ of $\mathrm{HNO}_{3}$ (digestion time, $30 \mathrm{~min}$; temperature, $200^{\circ} \mathrm{C}$ ). The resulting solution was diluted with deionized water to $25 \mathrm{~mL}$.

Elements were determined using a Hitachi Polarized Zeeman atomic absorption spectrometer ZA3000 series (Hitachi High-Technologies Corporation, Tokyo, Japan). $\mathrm{Ca}, \mathrm{K}, \mathrm{Na}$, and $\mathrm{Mg}$ were determined by flame method (FAAS) in an air-acetylene flame. The concentrations of $\mathrm{Al}, \mathrm{As}, \mathrm{Cd}, \mathrm{Cu}, \mathrm{Fe}, \mathrm{Ni}, \mathrm{Pb}$, and $\mathrm{Zn}$ were measured using a flameless graphite furnace (GFAAS). According to the analytical methodology presented by the APHA (2005), dedicated matrix modifiers were used for selected elements, such as palladium in 5\% $\mathrm{HNO}_{3}$ (Sigmatik, Poland) and cesium chloridelanthanum chloride buffer solution acc. to Schinkel (Merck, Germany).

Calibration curves were made using certified standard solutions (1000 mg/L) from Scharlau (Spain) for $\mathrm{Mg}, \mathrm{Ca}, \mathrm{K}, \mathrm{Na}$, and $\mathrm{Fe}$, and from Merck (Germany) for $\mathrm{Al}, \mathrm{As}, \mathrm{Cd}, \mathrm{Cu}, \mathrm{Ni}, \mathrm{Pb}$, and $\mathrm{Zn}$. The detection limits were $0.3 \mathrm{ppb}$ (for $\mathrm{Al}$ ), $0.2 \mathrm{ppb}$ (for $\mathrm{Cd}$ and $\mathrm{Pb}$ ), $0.5 \mathrm{ppb}$ (for $\mathrm{Fe}$ and $\mathrm{Ni}$ ), $0.1 \mathrm{ppb}$ (for $\mathrm{Zn}$ ), $2.0 \mathrm{ppb}$ (for As), and $1.0 \mathrm{ppb}$ (for $\mathrm{Cu}$ ).

The analytical method was tested using reference fish muscle ERM-BB422 (European Reference Materials, European Commission-Joint Research Center, Institute for Reference Materials and Measurements, Geel, Belgium). The recovery of elements ranged from 95 to $105 \%$, and the precision for the reference materials ranged from 1.2 to $10.1 \%$ (Table 1 ). 
Table 1 Recovery of elements from the reference material (fish muscle ERM-BB422)

\begin{tabular}{|c|c|c|c|c|c|}
\hline \multirow[t]{2}{*}{ Element } & \multirow{2}{*}{$\begin{array}{l}\text { Certified value } \\
\text { ppm }\end{array}$} & \multicolumn{2}{|c|}{ Determined value $(N=3)$} & \multirow{2}{*}{$\begin{array}{l}\text { Recovery } \\
\%\end{array}$} & \multirow[t]{2}{*}{ SD } \\
\hline & & & SD & & \\
\hline $\mathrm{Ca}$ & 3420 & 3487 & 61 & 102 & 1.8 \\
\hline $\mathrm{K}$ & 21,400 & 21,643 & 895 & 101 & 4.2 \\
\hline $\mathrm{Mg}$ & 1370 & 1304 & 17 & 95 & 1.2 \\
\hline $\mathrm{Na}$ & 2800 & 2937 & 91 & 105 & 3.2 \\
\hline $\mathrm{Fe}$ & 9.4 & 9.0 & 0.3 & 96 & 3.4 \\
\hline $\mathrm{Cu}$ & 1.67 & 1.69 & 0.09 & 101 & 5.4 \\
\hline $\mathrm{Zn}$ & 16 & 16.8 & 0.8 & 105 & 1.6 \\
\hline $\mathrm{Cd}$ & 0.0075 & 0.0072 & 0.0008 & 96 & 10.1 \\
\hline
\end{tabular}

Statistical analysis

Statistical analysis was performed using Statistica v12.0 (StatSoft Inc 2016). Means and standard deviations (SD) were determined. Differences in the accumulation of elements between the Harris mud crab, water, and sediments were calculated using a Kruskal-Wallis test. The level of significance for the statistical tests was $p<0.05$.

\section{Results and discussion}

The Harris mud crab is the smallest invasive crab species of the genus Brachyura in the Baltic Sea
(Czerniejewski and Rybczyk 2008; Hegele-Drywa and Normant 2014). In the eastern part of the Polish Baltic coast, the width of its carapace ranges from 1.96 to $21.4 \mathrm{~mm}$ (Hegele-Drywa and Normant 2014; HegeleDrywa et al. 2014), and in the western part from 5.6 to 22.9 mm (Czerniejewski and Rybczyk 2008; Czerniejewski 2009). In the results presented by Normant et al. (2004) and Roche and Torchin (2007), crabs caught on the central coast of the southern Baltic were quite large in size (the width of the carapace was from 13 to $23 \mathrm{~mm}$ ), which indicates that they were mature and ready for breeding. The lack of smaller individuals in the samples resulted from the parameters of the equipment used for fishing. The average carapace

Table 2 Dry weight, length, and width of the Harris mud crab (Rhithropanopeus harrisii) and the levels of elements in the body ( $n=24)$

\begin{tabular}{|c|c|c|c|c|c|}
\hline \multicolumn{2}{|l|}{ Indicator } & \multirow{2}{*}{$\frac{\text { Mean }}{0.936}$} & \multirow{2}{*}{$\frac{\text { Minimum }}{0.300}$} & \multirow{2}{*}{$\frac{\text { Maximum }}{2.254}$} & \multirow{2}{*}{$\frac{\mathrm{SD}}{0.426}$} \\
\hline Dry weight & $\mathrm{g}$ & & & & \\
\hline Width & $\mathrm{mm}$ & 18.0 & 13.0 & 23.0 & 2.19 \\
\hline Length & & 15.0 & 10.0 & 20.0 & 2.05 \\
\hline $\mathrm{Ca}$ & ppm d.w. & 246,000 & 229,000 & 275,000 & 10,000 \\
\hline $\mathrm{Mg}$ & & 11,000 & 8680 & 12,900 & 935 \\
\hline $\mathrm{Na}$ & & 8610 & 8080 & 9490 & 416 \\
\hline K & & 3780 & 2830 & 4310 & 284 \\
\hline $\mathrm{Fe}$ & & 1830 & 1040 & 2590 & 366 \\
\hline $\mathrm{Al}$ & & 184 & 111 & 330 & 67 \\
\hline $\mathrm{Zn}$ & & 62.6 & 51.5 & 87.6 & 7.7 \\
\hline $\mathrm{Cu}$ & & 25.0 & 18.4 & 37.3 & 4.8 \\
\hline $\mathrm{Ni}$ & & 0.543 & 0.378 & 1.042 & 0.181 \\
\hline As & & 0.288 & 0.210 & 0.436 & 0.063 \\
\hline $\mathrm{Pb}$ & & 0.140 & 0.108 & 0.238 & 0.029 \\
\hline $\mathrm{Cd}$ & & 0.0017 & 0.0003 & 0.0070 & 0.0019 \\
\hline
\end{tabular}

$S D$, standard deviation 
Table 3 Concentration of elements in the water and bottom sediments from the sampling area $(n=9)$

\begin{tabular}{|c|c|c|c|c|c|}
\hline \multirow[t]{2}{*}{ Element } & & \multicolumn{2}{|l|}{ Water } & \multicolumn{2}{|c|}{ Sediments } \\
\hline & & Mean & $\mathrm{SD}$ & Mean & SD \\
\hline $\mathrm{Ca}$ & ppm & 126 & 5 & 5122 & 675 \\
\hline $\mathrm{Mg}$ & & 270 & 32 & 402 & 11 \\
\hline $\mathrm{Na}$ & & 1868 & 82 & 52 & 23 \\
\hline K & & 77.2 & 1.8 & 172 & 24 \\
\hline $\mathrm{Fe}$ & & 0.502 & 0.245 & 1429 & 180 \\
\hline $\mathrm{Al}$ & & 0.257 & 0.179 & 645 & 124 \\
\hline $\mathrm{Zn}$ & & 1.217 & 0.281 & 2.741 & 0.186 \\
\hline $\mathrm{Cu}$ & & 0.517 & 0.116 & 1.672 & 0.492 \\
\hline $\mathrm{Ni}$ & & 0.0031 & 0.0016 & 1.264 & 0.204 \\
\hline As & & 0.0009 & 0.0004 & 0.292 & 0.015 \\
\hline $\mathrm{Pb}$ & & 0.0014 & 0.0002 & 0.748 & 0.071 \\
\hline $\mathrm{Cd}$ & & 0.0003 & 0.0001 & 0.0068 & 0.0008 \\
\hline
\end{tabular}

$S D$, standard deviation

width of the individuals in our study (15 mm, Table 2) matched the populations studied in Czerniejewski and Rybczyk (2008) and Czerniejewski (2009).

In our study, the concentrations of the elements determined in the whole body (including meat and exoskeleton) of the Harris mud crab could be arranged in the following descending order: $\mathrm{Ca}>\mathrm{Mg}>\mathrm{Na}>\mathrm{K}>$ $\mathrm{Fe}>\mathrm{Al}>\mathrm{Zn}>\mathrm{Cu}>\mathrm{Ni}>\mathrm{As}>\mathrm{Pb}>\mathrm{Cd}$ (Table 2). That order was different in the surrounding water $(\mathrm{Na}>$
$\mathrm{Mg}>\mathrm{Ca}>\mathrm{K}>\mathrm{Zn}>\mathrm{Cu}>\mathrm{Fe}>\mathrm{Al}>\mathrm{Ni}>\mathrm{Pb}>\mathrm{As}>\mathrm{Cd})$ and bottom sediments $(\mathrm{Ca}>\mathrm{Fe}>\mathrm{Al}>\mathrm{Mg}>\mathrm{K}>\mathrm{Na}>$ $\mathrm{Zn}>\mathrm{Cu}>\mathrm{Ni}>\mathrm{Pb}>\mathrm{As}>\mathrm{Cd}$ ) (Table 3). The concentrations of all elements were significantly higher in the crabs than in the water, with $\mathrm{Ca}, \mathrm{Mg}, \mathrm{Na}, \mathrm{K}, \mathrm{Fe}, \mathrm{Zn}$, and $\mathrm{Cu}$ significantly higher than in the bottom sediments (Table 4). Such a disparity may indirectly indicate the level of contamination of the studied area, especially with non-essential elements. The Baltic Sea is known to be exposed to high levels of anthropogenic stress due to its location and hydrology (Hendożko et al. 2010; Szefer et al. 2009). However, the highest levels of pollution of the southern coast of this sea, including contamination with heavy metals, are found in the area of the Vistula and Odra estuaries. For example, in the sediments of the Bay of Gdańsk, Szefer et al. (2009) recorded As > $4 \mathrm{ppm}, \mathrm{Pb}>30 \mathrm{ppm}$, and $\mathrm{Cd}>0.5 \mathrm{ppm}$. Similarly high concentrations of these elements were also recorded in sediments from the Pomeranian Bay or Stupsk Farrow. The significantly higher concentrations of non-essential elements observed by Szefer et al. (2009) and Hendożko et al. (2010), in comparison with our results, may be due to varying physicochemical properties of sediments across the Baltic Sea coast. The Bay of Gdańsk and Pomeranian Bay are areas which accumulate contaminants and terrigenous material (including organic matter) transported by the Vistula and Odra rivers, respectively. The central-southern Baltic coast is beyond the direct inflow of such high loads of anthropogenic pollution, and the bottom sediments of this area consist

Table 4 The Kruskal-Wallis test for the significance of elemental differences in the Harris mud crab (HMC), water, and bottom sediments

\begin{tabular}{|c|c|c|c|c|c|c|c|}
\hline Element & & Water & Bottom sediments & Element & & Water & Bottom sediments \\
\hline \multirow[t]{2}{*}{$\mathrm{Ca}$} & HMC & $0.00000^{*}$ & $0.00174 *$ & $\mathrm{Zn}$ & HMC & $0.00000^{*}$ & $0.00174 *$ \\
\hline & Water & & 0.35894 & & Water & & 0.35894 \\
\hline \multirow[t]{2}{*}{$\mathrm{Mg}$} & $\mathrm{HMC}$ & $0.00000^{*}$ & $0.00173^{*}$ & $\mathrm{Cu}$ & $\mathrm{HMC}$ & $0.00000 *$ & $0.00174^{*}$ \\
\hline & Water & & 0.35894 & & Water & & 0.35894 \\
\hline \multirow[t]{2}{*}{$\mathrm{Na}$} & $\mathrm{HMC}$ & $0.00000^{*}$ & $0.00000^{*}$ & $\mathrm{Ni}$ & HMC & $0.00174 *$ & $0.00174 *$ \\
\hline & Water & & 0.35894 & & Water & & $0.00000 *$ \\
\hline \multirow[t]{2}{*}{ K } & $\mathrm{HMC}$ & $0.00000^{*}$ & $0.00173^{*}$ & As & HMC & $0.00006^{*}$ & 1.00000 \\
\hline & Water & & 0.35894 & & Water & & $0.00035^{*}$ \\
\hline \multirow[t]{2}{*}{$\mathrm{Fe}$} & HMC & $0.00001^{*}$ & $0.02957^{*}$ & $\mathrm{~Pb}$ & HMC & $0.00174^{*}$ & $0.00174 *$ \\
\hline & Water & & 0.11395 & & Water & & $0.00000^{*}$ \\
\hline \multirow[t]{2}{*}{$\mathrm{Al}$} & $\mathrm{HMC}$ & $0.00174 *$ & $0.00174^{*}$ & $\mathrm{Cd}$ & HMC & $0.01571 *$ & $0.00174 *$ \\
\hline & Water & & $0.00000^{*}$ & & Water & & $0.00001 *$ \\
\hline
\end{tabular}

*Statistically significant, $p<0.05$ 
Table 5 Comparison of $\mathrm{Ca}, \mathrm{Mg}, \mathrm{Na}, \mathrm{K}$, and $\mathrm{Fe}$ concentrations in crabs from different regions

\begin{tabular}{|c|c|c|c|c|c|c|}
\hline \multirow[t]{2}{*}{ Species name } & \multirow[t]{2}{*}{ Habitat } & \multicolumn{5}{|l|}{ Metals } \\
\hline & & $\begin{array}{l}\mathrm{Ca} \\
\mathrm{ppm}\end{array}$ & $\mathrm{Mg}$ & $\mathrm{Na}$ & $\mathrm{K}$ & $\mathrm{Fe}$ \\
\hline Paratelphusa lamellifrons ${ }^{\mathrm{a}}$ & Padma River, Bangladesh & $5385-5640$ & - & - & $1037-1192$ & $423-487$ \\
\hline Uca tangeri $^{\mathrm{b}}$ & The Cross River, Nigeria & 7180 & 7670 & 6300 & 6060 & 1560 \\
\hline Callinectes amnicola $^{\mathrm{b}}$ & The Cross River, Nigeria & $4020-5640$ & $1250-1800$ & $2600-4410$ & $2000-3610$ & $980-1710$ \\
\hline Podopthalmus vigil ${ }^{\mathrm{c}}$ & Parangipettai, India & 1567 & - & 3010 & 4780 & 3570 \\
\hline Callinectes amnicola $^{\mathrm{d}}$ & Ojo River, Nigeria & $800-900$ & - & - & - & $690-820$ \\
\hline Cardisoma rotundum $^{\mathrm{e}}$ & Bay of Bengal, India & 2168 & 765 & 1024 & 1369 & 671 \\
\hline Callinectes sapidus ${ }^{\mathrm{f}}$ & Akyazan Lagoon, Turkey & $3982-4554$ & $744-1170$ & $6639-11,330$ & $628-691$ & - \\
\hline Calappa lophus ${ }^{\mathrm{g}}$ & Parangipettai, India & $2346-2452$ & $786-1609$ & $1114-1488$ & $1467-1632$ & $64.5-68.6$ \\
\hline Callinectes sapidus $^{\mathrm{h}}$ & The Acquatina Lagoon, Italy & 1196 & 3500 & 1883 & 3020 & 3 \\
\hline Eriphia verrucosa $^{\mathrm{h}}$ & The Acquatina Lagoon, Italy & 4567 & 6600 & 3259 & 2784 & 4.6 \\
\hline Cancer pagurus $^{\mathrm{h}}$ & The Acquatina Lagoon, Italy & 1286 & 4200 & 2120 & 3881 & 5.7 \\
\hline Podopthalmus vigil ${ }^{\mathrm{i}}$ & Parangipettai, India & $114-145$ & $9.9-25.0$ & $115-158.9$ & - & $74.5-133$ \\
\hline Charybdis natator ${ }^{\mathrm{j}}$ & Parangipettai, India & $115-234$ & $182-688$ & $364-523$ & $248-453$ & $10-25$ \\
\hline Sudananautes africanus ${ }^{\mathrm{k}}$ & River Osun, Nigeria & $279-330$ & $222-283$ & $207-260$ & $153-300$ & $71-97$ \\
\hline Eriphia verrucosa $a^{1}$ & Sinop coast, Turkey & 8968 & 1014 & 23,000 & 30,350 & 129 \\
\hline Cancer pagurus $^{\mathrm{m}}$ & Scottish coast & $200-19,260$ & $72-900$ & $1100-18,780$ & $1080-4880$ & $3.2-45$ \\
\hline
\end{tabular}

${ }^{a}$ Islam et al. (2016)

b Jimmy and Arazu (2012)

${ }^{\mathrm{c}}$ Sudhakar et al. (2011)

${ }^{\mathrm{d}}$ Moronkola et al. (2011)

e Silambarasan et al. (2015)

${ }^{\mathrm{f}}$ Kü ükgülmez et al. (2006)

${ }^{g}$ Kathirvel et al. (2014)

${ }^{\mathrm{h}}$ Zotti et al. (2016)

${ }^{\mathrm{i}}$ Soundarapandian et al. (2014)

${ }^{\mathrm{j}}$ Soundarapandian et al. (2013)

${ }^{\mathrm{k}}$ Adeyeye et al. (2010)

${ }^{1}$ Erdem et al. (2015)

${ }^{\mathrm{m}}$ Barrento et al. (2009)

mainly of sand, which accumulates less metals than organic material, an important component of the sediments studied by Szefer et al. (2009) and Hendożko et al. (2010).

As in the conclusions of Hendożko et al. (2010), the lower concentrations of $\mathrm{Al}, \mathrm{Ni}, \mathrm{Cd}$, and $\mathrm{Pb}$ in crabs than in sediments found in our study could be due to the low lability of these metals and consequently their low bioavailability to crabs. Although the influence of sediment geochemistry on the bioavailability of heavy metals is not yet fully understood, it is known that it depends on, among others, the binding of elements with fine sand particles, binding force, redox potential, salinity of water, or type of solid phase (Marmolejo-Rodriquez et al. 2007). Nevertheless, it is known that for benthic organisms, including crabs, metals that are easily extracted from sediments or dissolved in water are particularly bioavailable (Hendożko et al. 2010).

Generally, it can be concluded that the very high concentrations of $\mathrm{Ca}$ and $\mathrm{Mg}$ observed in the Harris mud crabs in our study $(246,000$ and 11,000 ppm respectively) were mainly the levels of these elements in their exoskeletons than in the flesh. This is particularly true for $\mathrm{Ca}$, which in the form of calcium carbonate, in addition to chitin and proteins, is the main constituent of the crustacean exoskeleton structure (Pires et al. 2017). 
Table 6 Comparison of essential and non-essential metals concentrations in crabs from different regions

\begin{tabular}{|c|c|c|c|c|c|c|c|}
\hline Species name & Habitat & $\begin{array}{l}\mathrm{Cu} \\
\mathrm{ppm}\end{array}$ & $\mathrm{Zn}$ & $\mathrm{Pb}$ & $\mathrm{Cd}$ & $\mathrm{Al}$ & $\mathrm{Ni}$ \\
\hline Xenograpsus testudinatus ${ }^{\mathrm{a}}$ & Kueishan Island, Taiwan & $53-290$ & $119-610$ & $1.83-2.64$ & $0.49-1.29$ & - & $0.95-4.76$ \\
\hline Eriocheir sinensis ${ }^{\mathrm{b}}$ & Odra Estuary, Poland & $3.17-21.9$ & $1.15-26.6$ & $0.29-0.61$ & $0.016-0.025$ & $2.64-3.49$ & $0.28-2.71$ \\
\hline Rhithropanopeus harrisii & Gujarat Purna Estuary, India & $6.4-37.1$ & $32-192$ & - & - & - & $16-134$ \\
\hline Charybdis longicollis $^{\mathrm{d}}$ & Iskenderun Bay, Turkey & $77.5-935$ & $32.5-805$ & - & $25.4-111$ & - & - \\
\hline Scylla serrata ${ }^{\mathrm{e}}$ & Dapeng Bay, Taiwan & 68.98 & 227 & 0.06 & 0.18 & - & 1.03 \\
\hline Portunus pelagicus ${ }^{\mathrm{e}}$ & & $9.9-26.2$ & $39.9-48.7$ & 1.28 & 0.41 & - & $0.45-0.78$ \\
\hline Thalamita crenata & & $6.6-25.1$ & $43.6-50.5$ & $0.16-0.83$ & $0.05-0.30$ & - & $0.16-0.39$ \\
\hline Scylla serrata ${ }^{\mathrm{e}}$ & & $56.8-192$ & $17.5-78.5$ & $1.34-3.70$ & $1.22-2.71$ & - & $1.04-1.70$ \\
\hline
\end{tabular}

\footnotetext{
${ }^{a}$ Peng et al. (2011)

${ }^{\mathrm{b}}$ Nędzarek et al. (2017)

${ }^{\mathrm{c}}$ Dange and Manoj (2015)

${ }^{\mathrm{d}}$ Firat et al. (2008)

${ }^{\mathrm{e}} \mathrm{Wu}$ (2006)
}

For example, in the study by Boßelmann et al. (2007), the exoskeletons of crustaceans Maja squinado contained $17.3-27.8 \% \mathrm{Ca}$ and $1-1.4 \% \mathrm{Mg}$, while Pires et al. (2017) found from about 30.8 to about $56.6 \% \mathrm{Ca}$ in Cancer pagurus. Fulton and Fairchild (2013), in their analysis of the whole body of Carcinus maenas found much lower levels, $5.7 \% \mathrm{Ca}$ and $0.22 \% \mathrm{Mg}$ as concentrations of these elements are much lower in crustacean flesh, and also exhibiting a wide range of concentrations from 110 to $5640 \mathrm{ppm}$ for $\mathrm{Ca}$, and from 72 to $7670 \mathrm{ppm}$ for $\mathrm{Mg}$ (for comparison, see Table 5).
In our study, high concentrations were also recorded for $\mathrm{Na}, \mathrm{K}$, and $\mathrm{Fe}(8610 \mathrm{ppm}, 3780 \mathrm{ppm}$, and $1830 \mathrm{ppm}$, respectively). The levels of these elements in crustaceans may occur in broad ranges, as shown in Table 5, ranging from 115 to $23,000 \mathrm{ppm}$ for $\mathrm{Na}$; from 153 to $4880 \mathrm{ppm}$ for $\mathrm{K}$, and from 3 to $1710 \mathrm{ppm}$ for $\mathrm{Fe}$ (Table 5). Their concentrations in living organisms are usually high due to their significant role in physiological functions, and their high variability is related to various factors, e.g., sexual dimorphism or the season of catch (Jimmy and Arazu 2012; Islam et al. 2016). The
Fig. 2 Variance analysis ANOVA $(p<0.05)$ of variation in arsenic distribution in Harris mud crab (HMC), water, and sediments; a, b values marked with the same index do not statistically significantly differ




Table 7 Comparison of As concentrations in crabs from different regions

\begin{tabular}{|c|c|c|}
\hline Species & Habitat & $\begin{array}{l}\text { As } \\
\text { ppm }\end{array}$ \\
\hline Rhithropanopeus harrisii ${ }^{\mathrm{a}}$ & South Baltic Sea, Poland & $0.288 \pm 0.063$ \\
\hline Eriocheir sinensis $^{\mathrm{b}}$ & Odra Estuary, Poland & $0.035-0.111$ \\
\hline Portunus pelagicus $^{\mathrm{c}}$ & The Persian Gulf, Iran & $0.08-0.22$ \\
\hline Portunus pelagicus $^{\mathrm{d}}$ & Gulf of Thailand, Thailand & $4.75 \pm 2.10$ \\
\hline Uca tangeri ${ }^{\mathrm{e}}$ & Guadalquivir Estuary, Spain & $1.76 \pm 0.08$ \\
\hline King $\operatorname{crab}^{\mathrm{f}}$ & Norwegian surveillance program & $26.0 \pm 3.0$ \\
\hline $\mathrm{Crab}^{\mathrm{g}}$ & Bo Sea, China & $0.76 \pm 0.02$ \\
\hline
\end{tabular}

${ }^{a}$ Own data

${ }^{\mathrm{b}}$ Nędzarek et al. (2017)

${ }^{\mathrm{c}}$ Khoramnejadian and Fatemi (2015)

${ }^{\mathrm{d}}$ Ruangwises and Ruangwises (2011)

${ }^{\mathrm{e}}$ Suner et al. (1999)

${ }^{\mathrm{f}}$ Sloth et al. (2005)

${ }^{\mathrm{g}} \mathrm{Li}$ et al. (2003)

seasonal and sex-specific differences are most probably related to the spawning cycle and differences in metabolism, influencing feeding, reproductive state, and weight (Legras et al. 2000).

The concentration of $\mathrm{Fe}$ in the Harris mud crab was about $22 \%$ higher than in the bottom sediments, which were also rich in this metal (1430 ppm, Table 3). Despite this significant difference $(p=0.02957)$, it can be concluded (after Rainbow 2007) that the adsorption of $\mathrm{Fe}$ from sediments on the surface of the carapace could be a significant factor responsible for its concentration in the crab's body. The carapace is made of chitin, which has a high sorptive capacity for metals (Rana et al. 2009). This process could also have been behind the relatively high concentrations of $\mathrm{Al}$ and $\mathrm{Ni}$ in the Harris mud crab (the concentrations in sediments were higher than in the crab, more than 3 times for $\mathrm{Al}$, and more than 2 times for $\mathrm{Ni}$ ).

The next in terms of concentration were $\mathrm{Zn}$ and $\mathrm{Cu}$ (62.6 ppm and $25 \mathrm{ppm}$, respectively) which did not exceed levels recorded in other species of crabs (see Table 6). The concentrations of $\mathrm{Zn}$ and $\mathrm{Cu}$ in the Harris mud crab were higher than in the bottom sediments (more than 20 times for $\mathrm{Zn}$ and about 15 times for $\mathrm{Cu}$ ). A similar disproportion between $\mathrm{Zn}$ and $\mathrm{Cu}$ levels in crustaceans and bottom sediments was demonstrated by MacFarlane et al. (2000) in the Semaphore crab (Heloecius cordiformis). These metals accumulated in the body of crabs, and especially in the liver. For example, $\mathrm{Cu}$ in the liver of $H$. cordiformis ranged from 200 to $600 \mathrm{ppm}$ despite $\mathrm{Cu}$ concentrations in sediments ranging from 0.6 to $135 \mathrm{ppm}$ (MacFarlane et al. 2000).

$\mathrm{Zn}$ and $\mathrm{Cu}$ are classified as heavy metals essential for animal metabolism in lower concentrations, yet toxic in excess (Rainbow 1985, 2007). Invertebrates use physiological and biochemical detoxification processes that allow them to regulate $\mathrm{Zn}$ and $\mathrm{Cu}$ concentrations and accumulate them in tissues to survive high environmental concentrations of these metals (Rainbow 1985; MacFarlane et al. 2000; Firat et al. 2008). This ability is non-existent with respect to non-essential metals, such as $\mathrm{Pb}$ or $\mathrm{Cd}$, which accumulate permanently in tissues and also then exhibit toxic properties (Rainbow 2007).

Comparing with literature data (see Table 6), the concentrations of $\mathrm{Pb}(0.14 \mathrm{ppm})$ and $\mathrm{Cd}(0.0017 \mathrm{ppm})$ recorded in our research can be classified as low, considerably lower than the Standard of Maximum Levels of Contaminants in Foods - for both elements maximum 0.50 ppm (FAO 2003, Commission Regulation No. 1881/2006). These metals in the studied crabs could originate from sediments (containing 5 times more $\mathrm{Pb}$ and 4 times more $\mathrm{Cd}$ than the examined crustaceans). The bioavailability and uptake of non-essential elements by crustaceans depends on different environmental factors such as temperature, salinity, chelating agents, as well as the concentration of these metals in the environment. As benthic organisms have close contact with sediment particles, they accumulate heavy metals via adsorption and food intake (MacFarlane et al. 2000; Firat et al. 2008; Dange and Manoj 2015; Nędzarek et al. 2017; Pires et al. 2017).

Bottom sediments could also have been a source of As in the studied crabs, which reached a concentration of $0.288 \mathrm{ppm}$, not significantly different $(p=1.0000)$ from sediment concentrations ( $0.291 \mathrm{ppm})$, but 300 times higher than in the water (Fig. 2). The sediment concentrations of As were lower than those recorded in deep-water zones of the Baltic Sea. For example, in Bornholm Deep (depth $118 \mathrm{~m}$ ) sediment As concentration was $17 \mathrm{ppm}$, in Gotland Deep (depth 118 m) 13.3 ppm, in the Gulf of Gdańsk (depth $52 \mathrm{~m}$ ) $5.1 \mathrm{ppm}$. A similarly low sediment concentration of As (5.7 ppm) was recorded in Stupsk Farrow (depth of $31 \mathrm{~m}$; distance to the shore, $32 \mathrm{~km}$ ), the region nearest to our research area (Bełdowski et al. 2016). This difference allows us to conclude that the studied crabs caught in the coastal region were not exposed to elevated concentrations of this potentially toxic element. As a consequence, its accumulation was lower than the recorded 
concentrations in various crab species by other authors (see Table 7) and did not exceed the International Standards for Maximum Levels of As concentrations in food.

The reported concentrations of $\mathrm{Cd}, \mathrm{Pb}$, and $\mathrm{As}$ in the Harris mud crab were also below the acceptable concentrations of these elements in feed as standardized by Directive 2002/32/EC, according to which feed materials of animal origin may contain a maximum of $2 \mathrm{ppm}$ $\mathrm{Cd}, 10 \mathrm{ppm} \mathrm{Pb}$, and 25 ppm As.

\section{Summary}

The waters in the survey area and bottom sediments can be considered poorly contaminated with non-essential elements and the bioavailability of $\mathrm{Al}, \mathrm{Ni}, \mathrm{Cd}$, and $\mathrm{Pb}$ for Harris mud crabs is low.

The obtained results show that the Harris mud crab is rich in $\mathrm{Ca}, \mathrm{Mg}$, $\mathrm{Na}, \mathrm{K}, \mathrm{Fe}$, and essentials metals such as $\mathrm{Cu}$ and $\mathrm{Zn}$, and can be a valuable source of these elements. The low concentrations of non-essential metal such as $\mathrm{Pb}$, $\mathrm{Cd}$, and As will not pose a threat to consumers.

We can therefore conclude that the invasive Harris mud crab from this Baltic region can be used to prepare well-balanced feed for fish and other animals, and that the introduction of commercial fishing of this crab could help to reduce its population.

Open Access This article is distributed under the terms of the Creative Commons Attribution 4.0 International License (http:// creativecommons.org/licenses/by/4.0/), which permits unrestricted use, distribution, and reproduction in any medium, provided you give appropriate credit to the original author(s) and the source, provide a link to the Creative Commons license, and indicate if changes were made.

\section{References}

Adeyeye, E. I., Olanlokun, J. O., \& Falodun, T. O. (2010). Proximate and mineral composition of whole body, flesh and exoskeleton of male and female common West African fresh water crab Sudananautes africanus africanus. Polish Journal of Food and Nutrition Science, 60(3), 213-216.

Antonowicz, J., Grobela, M., Opalińska, M., \& Motała, R. (2017). Heavy metals in beach deposits, bottom sediments of a Baltic fishing port and surface water. Baltic Coastal Zone, 21, 211-224.

APHA. (2005). Standard methods for examination of water and wastewater (21th ed.pp. 20001-23710). Washington, D.C: American Public Health Association.

Barrento, S., Marques, A., Teixeira, B., Analceto, P., Carvalho, M. L., Vaz-Pires, P., \& Nunes, M. L. (2009). Macro and trace elements in two populations of brown crab Cancer pagurus: ecological and human health implications. Journal of Food Composition and Analysis 22, 65-71.

Bełdowski, J., Szubska, M., Emelyanov, E., Garnaga, G., Drzewińska, A., Bełdowska, M., Vanninen, P., Ostin, A., \& Fabisiak, J. (2016). Arsenic concentrations in Baltic sediments close to chemical munitions dumpsites. Deep-Sea Research II, 128, 114-122.

Boßelmann, F., Romano, P., Fabritius, H., Raabe, D., \& Epple, M. (2007). The composition of the exoskeleton of two crustacean: The American lobster Homarus americanus and the edible crab Cancer pagurus. Thermochimica Acta, 463, 65-68.

Buitendijk, A. L., \& Holthuis, L. B. (1949). Note on the Zuiderzee crab, Rhithropanopeus harrisii (Gould) subspecies tridentatus (Maitland). Zoologische Mededelingen, XXX, 7, 95-106.

Commission Regulation (EC) No 1881/2006 of 19 December 2006 setting maximum levels for certain contaminants in foodstuffs (Text with EEA relevance). pp 20. Official Journal of the European Union L 354/5 https://eur-lex. europa.eu/LexUriServ/LexUriServ.do?uri=OJ:L:2006:364 :0005:0024:EN:PDF. Accessed 10 Feb 2018.

Council Directive 98/83/EC of 3 November 1998 on the quality of water intended for human consumption. https://eur-lex. europa.eu/legalcontent/EN/TXT/?uri=CELEX:31998L0083. Accessed 9 Apr 2018

Czerniejewski, P. (2009). Some aspects of the population biology of the mud crab, Rhithropanopeus harrisii (Gould, 1841) in the Odra estuary, Poland. Oceanological and Hydrobiological Studies, 36(4), 49-62.

Czerniejewski, P., \& Rybczyk, A. (2008). Body weight, morphometry, and diet of the mud crab, Rhithropanopeus harrisii tridentatus (Maitland, 1874) in the Odra Estuary, Poland. Crustaceana, 81(11), 1289-1299.

Dange, S., \& Manoj, K. (2015). Bioaccumulation of heavy metals in sediment, polychaetes (annelid) worms, mud skipper and mud crab at Purna River Estuary, Navsari, Gujarat, India. International Journal of Current Microbiology and Applied Sciences, 4(9), 571-575.

Demel, K. (1953). A new species in the Baltic Sea fauna. Kosmos, 2, 105-106.

Demirak, A., Yilmaz, F., Tuna, A. L., \& Ozdemir, N. (2006). Heavy metals in water, sediment and tissues of Leuciscus cephalus from a stream in southwestern Turkey. Chemosphere, 63, 1451-1458.

Directive 2002/32/EC of the European Parliament and of the Council of 7 May 2002 on undesirable substances in animal feed. https://eurlex.europa.eu/legal-content/EN/TXT/?uri=CELEX\%3 A32002L0032. Accessed 10 Apr 2018.

Erdem, M. E., Turan, H., \& Kaya, Y. (2015). Mineral and trace element contents of warty crab (Eriphia verrucosa) and brown shrimp (Crangon crangon). Journal of Fisheries and Aquatic Sciences, 30(2), 26-31.

Fang, H. W., Huang, L., Wang, J. Y., He, G. J., \& Reible, D. (2016). Environmental assessment of heavy metal transport and transformation in the Hangzhou Bay, China. Journal Hazard Material, 302, 447-457.

FAO. (2003). Food and agriculture organization (FAO) heavy metal regulations-Faolex. Legal Notice no. 66/2003. 2003. http://faolex.fao.org/docs/pdf/eri42405.pdf. Acccessed 15 May2018.

Firat, O., Gok, G., Cogun, H. Y., Yuzereroglu, T. A., \& Kargin, F. (2008). Concentrations of $\mathrm{Cr}, \mathrm{Cd}, \mathrm{Cu}, \mathrm{Zn}$ and $\mathrm{Fe}$ in crab 
Charybdis longicollis and shrimp Penaeus semisulcatus. Environmental Monitoring and Assessment, 147, 117-123.

Fowler, A. E., Forsström, T., von Numers, M., \& Vesakoski, O. (2013). The North American mud crab Rhithropanopeus harrisii (Gould, 1841) in newly colonized Northern Baltic Sea: distribution and ecology. Aquatic Invasions, 8, 89-96. https://doi.org/10.3391/ai.2013.8.1.10.

Fulton, B. A., \& Fairchild, E. A. (2013). Nutritional analysis of whole green crab, Carcinus maenas, for application as a forage fish replacer in agrifeeds. Sustainable Agriculture Research, 2(3), 126-135. https://doi.org/10.5539/sar.v2n3p126.

Hegele-Drywa, J., \& Normant, M. (2014). Non-native crab Rhithropanopeus harrisii (Gould, 1894) - a new component of the benthic communities in the Gulf of Gdańsk (southern Baltic Sea). Oceanologia, 56(1), 1-15.

Hegele-Drywa, J., Normant, M., Szwarc, B., \& Podłuska, A. (2014). Population structure, morphometry and individual condition of non-native crab Rhithropanopeus harrisii (Gould, 1841), a recent colonizer of the Gulf of Gdańsk (southern Baltic Sea). Oceanologia, 56(4), 805-824.

HELCOM. (2011). Minutes of the second meeting of HELCOM CORESET expert workshop on biodiversity indicators (HELCOM CORESET BD 2/2011). Gothenburg, Sweden, 16-18 February 2011. https://portal.helcom. fi/Archive/Shared\%20Documents/CORESET\%20BD\%202$20113-1 \% 20$ Candidate $\% 20$ core $\% 20$ indicators.pdf. Accessed 11 Apr 2018.

Hendożko, E., Szefer, P., \& Warzocha, J. (2010). Heavy metals in Macoma balthica and extractable metals in sediments from the southern Baltic Sea. Ecotoxicology and Environmental Safety, 73, 152-163.

Islam, B., Mia, B., Razzaque, A., Sarker, M., Rahman, R., Jalil, A., Rahim, A., \& Roy, D. K. (2016). Investigation on mineral composition of freshwater crab (Paratelphusa lamellifrons) of Padma River near Rajshahi city, Bangladesh. International Journal of Fisheries and Aquatic Studies, 4(6), 236-240.

Jimmy, U. P., \& Arazu, V. N. (2012). The proximate and mineral composition of two edible crabs Callinectes amnicola and Uca tangeri (Crustecea: Decapoda) of the Cross River, Nigeria. Pakistan Journal of Nutrition, 11(1), 78-82.

Kathirvel, K., Eswar, A., Manikandarajan, T., Ramamoorthy, K., Sankar, G., \& Anbarasu, R. (2014). Proximate composition, amino acid, fatty acid and mineral analysis of box crab, Calappa lophus (Herbst, 1782) from Parangipettai, southeast coast of India. Journal of Environmental Science, Toxicology and Food Technology, 8(5), 50-57.

Ke, X., Gui, S., Huang, H., Zhang, H., Wang, C., \& Guo, W. (2017). Ecological risk assessment and source identification for heavy metals in surface sediment from the Liaohe River protected area, China. Chemosphere, 175, 473-481.

Khoramnejadian, S., \& Fatemi, F. (2015). Bioaccumulation of arsenic in blue swimmer crab. International Proceedings of Chemical, Biological and Environmental Engineering, 88, 59-64. https://doi.org/10.7763/IPCBEE.2015.V88.11.

Krzymiński, W. (2014). Wstępna ocena stanu środowiska wód morskich polskiej strefy Morza Bałtyckiego. Raport dla Komisji Europejskiej. (Initial assessment of the state of the marine environment in the Polish zone of the Baltic Sea. Report for the European Commission). Wyd. GIOŚ. Warszawa. http://www.gios.gov.pl/bip/zalaczniki/konsultacje spoleczne/folder A/wstepna ocena stanu srodowiska wod morskich.pdf. Accessed 01 May 2018.

Kujawa, S. (1957). Biology and cultivation of the crab R. harrisii tridentatus from the Vistula Lagoon. Wszechświat, 2, 57-59.

Kü ükgülmez, A., Celik, M., Yanar, Y., Ersoy, B., \& Crikrici, M. (2006). Proximate composition and mineral contents of the blue crab (Callinectes sapidus) breast meat, claw meat and hepatopancreas. International Journal of Food Science and Technology, 41, 1023-1026.

Legras, S., Mouneyrac, C., Amirad, J. C., Amirad-Triquet, C., \& Rainbow, P. S. (2000). Changes in metallothionein concentrations in response to variation in natural factors (salinity, sex, weight) and metal contamination in crabs from a metal rich-environment. Journal of Experimental Marine Biology and Ecology, 246, 259-279.

Li, W., Wei, C., Zhang, C., Van Hulle, M., Cornelis, R., \& Zhang, X. (2003). A survey of arsenic species in Chinese seafood. Food and Chemical Toxicology, 41, 1103-1110.

MacFarlane, G. R., Booth, D. J., \& Brown, K. R. (2000). The Semapfore crab, Heloecius cordifornis: bio-indication potential for heavy metals in estuarine systems. Aquatic Toxicology, 50, 153-166.

Marmolejo-Rodriquez, A. J., Prego, R., Meyer-Willerer, A., Shumilin, E., \& Cobelo-Garcia, A. (2007). Total and labile metals in surface sediments of the tropical river-estuary system of Marabasco (Pacific coast of Mexico): influence of an iron mine. Marine Pollution Bulletin, 55, 459-468.

Michalski, K. (1957). Rhithropanopeus harrisii sbsp. tridentatus (Mtl.) in the rivers Vistula and Motlawa. Przeglad Zoologiczny, 1(1), 68-69.

Moronkola, B. A., Olowu, R. A., Towide, O. O., \& Ayejuyo, O. O. (2011). Determination of proximate and mineral contents of crab (Callinectes amnicola) living on the shore of Ojo river, Lagos, Nigeria. Scientific Reviews and Chemical Communications, 1(1), 1-6.

Nędzarek, A., Czerniejewski, P., Drost, A., Harasimiuk, F., Machula, S., Tórz, A., \& Masalski, P. (2017). The distribution of elements in the body of invasive Chinese mitten crabs (Eriocheir sinensis H. Milne-Edwards, 1853) from Lake Dąbie, Poland. Journal of Food Composition and Analysis, 60, 1-9.

Nẹdzarek, A., Czerniejewski, P., \& Tórz, A. (2019). Macro- and trace elements in Chinese mitten crabs (Eriocheir sinensis) from Szczecin Lagoon, Poland - Implications for human health. Aquaculture, 506, 229-237. https://doi.org/10.1016/j. aquaculture.2019.03.042.

Normant, M., Miernik, J., \& Szaniawska, A. (2004). Remarks on the morphology and the life cycle of Rhithropanopeus harrisii sbsp. tridentatus (Maitland) from the Dead Vistula River. Oceanological and Hydrobiological Studies, 23(4), 93-102.

Peng, S. H., Hung, J. J., \& Hwang, J. S. (2011). Bioaccumulation of trace metals in the submarine hydrothermal vent crab Xenograpsus testudinatus off Kueishan Island, Taiwan. Marine Pollution Bulletin, 63, 396-401.

Petersen, C. (2006). Range expansion in the Northeast Pacific by an estuary mud crab - a molecular study. Biological Invasions, 8, 565-575.

Pires, C., Marques, A., Carvalho, M. L., \& Batista, I. (2017). Chemical characterization of Cancer pagurus, Maja Squinado, Necora puber and Carcinus maenas shells. 
Poultry, Fisheries and Wildlife Sciences, 5, 181. https://doi. org/10.4172/2375-446X.1000181.

Rainbow, P. S. (1985). Accumulation of $\mathrm{Zn}, \mathrm{Cu}$ and $\mathrm{Cd}$ by crabs and barnacles. Estuarine Coastal and Shelf Science, 21, 669-686.

Rainbow, P. S. (2007). Trace metal bioaccumulation: models, metabolic availability and toxicity. Environmental International, 33, 576-582.

Rana, M. S., Halim, M. A., Safiullah, S., Mamun Mollan, M., Azam, M. S., Goni, M. A., Kamal Hossain, M., \& Rana, M. M. (2009). Removal of heavy metal from contaminated water by biopolymer crab shell chitosan. Journal of Applied Science, 9(15), 2762-2769.

Roche, D. G., \& Torchin, M. E. (2007). Established population of the North American Harris mud crab, Rhithropanopeus harrisii (Gould 1841) (Crustacea: Brachyura: Xanthidae) in the Panama Canal. Aquatic Invasions, 2(3), 155-161.

Ruangwises, S., \& Ruangwises, N. (2011). Concentrations of total and inorganic arsenic in fresh fish, mollusks, and crustaceans from the Gulf of Thailand. Journal of Food Protection, 74(3), 450-455.

Silambarasan, R., Sankar, G., \& Ramamoorthy, K. (2015). Nutrional properties of the rainbow crab Cardisoma rotundum (Quoy \& Gaimard 1824) from Puducherry, southeast coast of Ondia. Indian Journal of Geo-Marine Science, 45(1), 173-179.

Sloth, J. J., Larsen, E. H., \& Julshamn, K. (2005). Survey of inorganic in marine animals and marine certified reference materials by anion exchange high-performance liquid chromatographyinductively coupled plasma mass spectrometry. Journal of Agriccultural and Food Chemistry, 53, 6011-6018.

Soundarapandian, P., Varadharajan, D., \& Sivasubramanian, C. (2013). Mineral composition of edible crab, Charybdis Natator Herbst (Crustacea: Decapoda). Journal of Bioanalysis and Biomedicine, 5, 099-101. https://doi. org/10.4172/1948-593X.1000088.

Soundarapandian, P., Varadharajan, D., \& Ravichandran, S. (2014). Mineral composition of edible crab Podophthalmus vigil Fabricius (Crustacea: Decapoda). Arthropods, 3(1), 20-26.

StatSoft Inc. (2016). Statistica (data analysis software system), version 12.1. http://www.statsoft.com. Accessed 15 May 2018.

Sudhakar, M., Raja, K., Anathan, G., \& Sampathkaumar, P. (2011). Compositional characteristics and nutritional quality of Podopthalmus vigil (Fabricius). Asian Journal of Biological Sciences, 4, 166-174. https://doi.org/10.3923 lajbs.2011.166.174.

Suner, M. A., Devesa, V., Munoz, O., Lopez, F., Montoro, R., Arias, A. M., \& Blasco, J. (1999). Total and inorganic arsenic in the fauna of the Guadalquivir estuary: environmental and human health implications. Science of the Total Environment, 242, 261-270.

Szefer, P. (2002). Metals, metalloids and radionuclides in the Baltic Sea ecosystem. Amsterdam: Elsevier Science B.V.

Szefer, P., Glasby, G. P., Geldon, J., Renner, R. M., Bjorn, E., Snell, J., Frech, W., \& Warzocha, J. (2009). Heavy-metal pollution of sediments from the Polish exclusive economic zone, southern Baltic Sea. Environmental Geology, 57, 847-862.

Turkmen, A., Turkmen, M., Tepe, Y., \& Akyurt, I. (2005). Heavy metals in three commercially valuable fish species from Iskenderun Bay, Northern East Mediterranean Sea, Turkey. Food Chemistry, 91, 167-172.

Turoboyski, K. (1973). Biology and ecology of the crab Rhithropanopeus harrisii sbsp. tridentatus. Marine Biology, 23, 303-313.

Uścinowicz, S., Szefer, P., \& Sokołowski, K. (2011). Trace elements in Baltic Sea sediments. In S. Uścinowicz (Ed.), Geochemistry of surface sediments of the Baltic Sea (pp. 214-274). Warsaw: Polish Geological Survey.

Vicente-Martorell, J. J., Galindo-Riano, M. D., Garcia-Vargas, M., \& Granado-Castro, M. D. (2009). Bioavailability of heavy metals monitoring water, sediments and fish species from a polluted estuary. Journal of Hazardous Materials, 162, 823-836.

$\mathrm{Wu}, \mathrm{R}$. (2006). Heavy metals accumulation of benthic invertebrates in Dapeng Bay, Pingtung. MS Thesis, National Kaohsiung Normal University, Kaohsiung, Taiwan.

Zotti, M., Del Coco, L., De Pascali, S. A., Migoni, D., Vizzini, S., Mancinelli, G., \& Fanizzi, F. P. (2016). Comparative analysis of the proximate and elemental composition of the blue crab Callinectes sapidus, the warty crab Eriphia verrucosa, and the edible crab Cancer pagurus. Heliyon, 2, 1-15. https://doi. org/10.1016/j.heliyon.

Publisher's note Springer Nature remains neutral with regard to jurisdictional claims in published maps and institutional affiliations. 